\title{
EDITORIAI
}

\section{LA BIOÉTICA EN EL CONSEJO DE EUROPA}

\section{Julia González Alonso.}

Subdirección General de Epidemiología, Promoción y Educación para la Salud. Dirección General de Salud Pública. Ministerio de Sanidad y Consumo.

El Consejo de Europa como Organismo Internacional básicamente fundado (el día 5 de mayo de 1949) para la salvaguarda y fomento de los derechos humanos y de las libertades fundamentales, y que en estos momentos cuenta con 40 Estados Miembros, viene estudiando, desde hace algunos años de manera detenida, todos aquellos problemas que los rápidos avances de la Medicina y de la Biología están planteando.

Como bien queda recogido en el Convenio recientemente aprobado, estos estudios proceden en su conjunto tanto de una constatación como de una inquietud. Constatación de la profunda evolución de los conocimientos en Medicina y Biología y de sus aplicaciones, en aquellas áreas en las que el hombre se encuentra directamente implicado. Inquietud por el carácter ambivalente que a menudo presentan estos avances, la ciencia sin duda en su complejidad ofrece luces y sombras.

Efectivamente, el conocimiento y comprensión de mecanismos fundamentales de la vida, abre posibilidades inéditas de intervención en el seno de los organismos vivos y con ello aplicaciones en el terreno sanitario, agrícola, energético, etc., pero también estas actuaciones pueden desarrollarse de manera que ocasionen riesgos y peligros para el hombre, su salud, el medio ambiente y en fin el propio equilibrio del mundo vivo.
Por ello los progresos de la medicina y de la biología deben acompañarse de manera inexcusable de una reflexión ética dirigida a proteger principios y valores sobre los que se apoya nuestra sociedad.

Merece la pena destacar, como en todos los foros en que estos temas son considerados, se resalta la importancia que de cara a esa reflexión tienen la celebración de debates públicos, y la necesidad de tener informada a la opinión pública al objeto de que sea la sociedad quien se manifieste al respecto desde su propio pluralismo.

La Bioética, ciencia que tiene como objetivo este tipo de análisis, se ha hecho famosa por un lado ante la necesidad y el intento de dar respuesta «científica» a tantos problemas que en este sentido tiene la sociedad y por otro lado ante la búsqueda afanosa por parte de los medios de comunicación de masas, de noticias sensacionalistas y nuevas a toda costa.

Por todo esto se hace necesario resaltar el lado beneficioso que sin duda la ciencia aporta y ello fundamentalmente, a partir de una toma de conciencia de lo que está en juego y de una actualización de todas las consecuencias.

A pesar de que ya existían instrumentos internacionales que aportaban protección y garantías en el terreno de los derechos humanos tanto individuales como sociales: la 
Declaración Universal de los Derechos Humanos; el Convenio de protección de los Derechos Humanos y de las Libertades Fundamentales; la Carta social europea; el Pacto Internacional sobre los Derechos civiles y políticos y el Pacto Internacional relativos a los Derechos económicos, sociales y culturales; el Convenio para la protección del individuo de cara al tratamiento automatizado de datos de carácter personal y el Convenio relativo a los Derechos del niño, entre otros, pareció oportuno desarrollar un instrumento de tipo específico en el Consejo de Europa.

Sería excesivamente extenso repasar aquí aunque fuese brevemente, el camino recorrido en este foro para esta materia, por lo que comentaremos únicamente el último trabajo realizado, por otro lado particularmente significativo, la aprobación del Convenio para la Protección de los Derechos del Hombre y de la Dignidad del Ser humano de cara a la aplicación de la Biología y de la Medicina, presentado a la firma de los distintos países en Oviedo el día 4 de abril de 1997, también conocido como Convenio sobre los Derechos Humanos y la Biomedicina, primer texto internacional elaborado en este campo.

Este Convenio marca la primacía y el bienestar del ser humano, señalando su prevalencia por encima del interés estricto de la ciencia y de la sociedad y somete toda actuación en el terreno de la salud y de la investigación a normas profesionales y reglas de conducta para todas las partes implicadas. Permitirá, por otro lado, la adopción de reglas comunes de actuación no solo entre los países miembros, sino que también podrá servir de base para la reflexión o para la inspiración en otros Estados. Es por cllo que aún en el supuesto de ser considerado «demasiado permisivo»o «excesivamente general», no cabe duda que constituye un soporte $y$ punto de referencia para el futuro.
En este sentido la Unión europea a través de una Resolución de su Parlamento sobre Biología y Medicina (DOCE, N. ${ }^{\circ}$ C 320/ 268), considera indispensable fijar normas éticas en el ámbito de la biología, de la biotecnología y de la medicina basadas en el respeto a la dignidad humana, y anima al Consejo de Europa a seguir trabajando en este sentido en tanto el Tratado de Maastricht no confiere a las instituciones comunitarias la potestad de fijar normas en el ámbito de los derechos humanos, de acuerdo a un dictamen del Tribunal de Justicia de las Comunidades Europeas de 28 de marzo de 1996.

El texto del Convenio está formado por un Preámbulo y 14 Capítulos con 38 artículos, en los cuales se contemplan temas como: el consentimiento de los afectados; la vida privada y el derecho a la información; prohibición de la utilización del cuerpo humano o partes del mismo con fines económicos; el genoma humano; la investigación científica; la donación de órganos y tejidos para trasplantes de donantes vivos y el debate público.

Con carácter general conviene destacar:

- Toda intervención en el terreno de la salud, tiene que estar precedida del consentimiento libre e informado del afectado, para el cual ha debido de recibir con anterioridad al mismo, la información más completa posible, respecto de las características, consecuencias y riesgos relativos a dicha intervención. Pudiendo en cualquier momento revocar el consentimiento prestado.

Caso particular y especialmente recogido en este Convenio, es la situación de aquellas personas que por motivos diversos no tienen capacidad para decidir por si mismas (menores, disminuidos psíquicos, enfermos en coma, etc.), en cuyo caso solo se podrá actuar cuando sea en su propio y directo beneficio y siempre que la autorización o consentimiento haya sido prestado por el tutor, autoridad o persona designada por la ley. 
Solo en determinadas situaciones de emergencia, podrá actuarse sin consentimiento.

- Toda persona tiene derecho a conocer la información completa recogida en relación con su salud. A título excepcional y siempre en interés del paciente, podrá limitarse este derecho.

- Se prohíbe toda discriminación en razón del patrimonio genético. La modificación del genoma humano solo podrá realizarse por razones preventivas, diagnósticas y terapéuticas y siempre que no suponga alteración en el genoma de la descendencia.

- La investigación científica solo se permite bajo determinadas y estrictas condiciones a saber: cuando no haya método alternativo; y los riesgos no sean desproporcionados respecto de los beneficios; y el proyecto de investigación haya sido aprobado por las instancias pertinentes y la persona implicada haya sido convenientemente informada y además haya prestado su consentimiento.

Estas características han de ser igualmente tomadas en caso de personas incapacitadas y complementadas en los términos ya expuestos de su particular consentimiento.
- Solo se pueden utilizar órganos y tejidos para trasplantes de donantes vivos, si no existe otro tipo de intervención, es necesario desde el punto de vista terapéutico del receptor y no se pueden obtener de personas fallecidas.

Este Convenio sobre los Derechos Humanos y la Biomedicina será desarrollado a través de varios protocolos adicionales. Se espera que el primero sea el relativo a Trasplantes de Organos y se pase a la firma el próximo año.

El Comité de Ministros ha solicitado por su parte, la preparación de otro con problemas relacionados con la genética como diagnósticos, tratamientos génicos, utilización de información sobre patrimonio genético, etc.

La situación en Europa es dispar, unos países tienen reglamentación muy estricta como Alemania, en tanto en otros es escasa y la permisividad en consecuencia mayor, situación de Italia. El Convenio viene a buscar la necesaria armonía en un terreno tan delicado como de obligado consenso, $\mathbf{y}$ representa el grado óptimo de aproximación entre las distintas posiciones, por ello debemos felicitarnos en la esperanza de que la dignidad humana, dentro de los limites pertinentes, pueda apoyar el desarrollo y progreso de la ciencia. 